\title{
THE SELECTION OF THE TYPES OF SHOES AND ITS IMPACT ON THE SKIN OF THE FEET
}

\author{
by Khalid Al Aboud
}

comment:

Piotr Brzezinski, MD PhD

\begin{tabular}{rr}
\hline Our Dermatol Online. 2012; 3(3): 224-225 & Date of submission: 10.04 .2012 / acceptance: 16.04 .2012 \\
Conflicts of interest: None
\end{tabular}

The author of the article raises the problem of impact of shoes on feet (skin of feet). Healthy feet are a very important factor in maintaining food physical condition. Well-fitted shoes are a matter of great importance for soldier's fitness and his availability [1]. Because of their static and motion functions, feet have impact on good physical and mental state as well as energetic attitude to life which have a specific/special meaning when the conditions of soldier's life during war as well as at the time of peace are to be considered, because they influence the readiness for battle of the military men.

Skin diseases among soldiers have always been considered as a very important problem demanding effective prophylactics. Detailed health recommendations for soldiers were presented in 1777 in the thesis of Benjamin Rush MD "Doctor Benjamin Rush health recommendations for soldiers"[2].

Skin changes on feet, apart from causing subjective affliction, in which pain is a main factor, are accompanied by objective changes. They appear in the form of inflammatory reactions of different levels of intensification and in consequence, they lead to decrease of the level of soldier's physical condition/ fitness. Intensification of the disease process may be a cause of partial or total exclusion of the soldier from training or battle field [3].

Also causing factors like hyperhidrosis of feet as well as blood supply and innervations disturbances may be important [4]. The main cause of these damages are, in most cases, abrasions and ruptures/breaks of epidermis-results of poorly fitted shoes. Intertrigo mechanical, unguis incarnates, foot blisters, sore spots on feet, congelatio, perniosis, trench foot, clavus (black heel) and phlegmon as an effect of superinfection of skin changes can be added to the list of other skin injuries which are related to poorly fitted shoes. A very common factor which supports inflammatory states of skin of feet are mechanical injuries which are not dressed or are dressed improperly what leads to bacterial and mycosis infections. Pitted keratolisis is a disease very common among soldiers and at the same time it is a disease typical for military environment $[5,6]$.
This fact is emphasized by Schissel and his partners among American soldiers [7] and by Mathis among soldiers of German army [9]. Jelliffe presents similar data concerning Nigerian soldiers [8]. Brzeziński describes, that percentage of pitted ketarolisis made $51,42 \%$ of bacterial diseases and $15,03 \%$ of all skin diseases recognized among soldiers in the period 2002-2005 [5,10].

Other social groups among which pitted ketarolisis may appear as frequently are sportsmen [11], farmers [12], people working by silk production [13] and homeless persons [14]. A note of significant increase of confirmed diagnosis of mycosis of feet was taken by Zhang and his partners among Chinese soldiers after a series of sea maneuvers [15]. Noguchi and his partners recognized feet mycosis among Japanese soldiers during summer and winter trainings [16]. Similar conclusions were formulated by Suo and his partners, whose research prove that feet mycosis infections may be a serious problem for soldiers during the peace as well as at the time of war and as a result they can delay soldiers' training and decrease the level of their activity during fight/ battle [17].

Idrosis and blood supply can be a factors which cause skin changes on feet with poorly fitted shoes. This relation was pointed out by Esterman and Pilotto during their researches/ examinations of injuries and microinjuries of feet among soldiers of Australian army [18]. Similar researches/ examinations conducted by Abdel-Fattah and his partners among soldiers of Saudi Arabian army point up/emphasize/ show that feet structure disturbances (platypodia) is not a factor of great risk of elimination of soldier from military training/maneuvers [19].

Di Benedetto and his partners presented extremely interesting thermographical examination of feet of 30 soldiers. Examination was conducted before a series of exercises and after the training. They found that new shoes and discomfort which is related to them can be a cause of feet skin damages detectable through thermography [20]. It was stated during this examination that pathological changes appeared during the exercises which took place between ten and twenty days after enrollment and new, poorly fitted shoes could be a reason of analyzed diseases. 
Experiences from stabilization missions in Iraq and Afghanistan show that feet protection against harmful impact of battle field factors can be strengthened only to a very little extent, however there is a possibility of minimizing the influence of mentioned harmful factors, for example, through well-fitted and modern shoes, soldier's education and proper dressing of existing, even the smallest small damages.

Every foot skin injury, even small one, which is not dressed or is dressed improperly can become a cause of serious infection and long-lasting unavailability of the soldier, which, in consequence, weakens fitness of the soldier and the readiness for battle of the fighting unit [21].

\section{REFERENCES}

1. Brzeziński P: [Assessment of the effectiveness of application antiseptics in prevention of foot skin inflammation]. N Dermatol Online. 2010; 2: 21-24.

2. Ilnicki S, Ilnicki P: [Doctor Benjamin Rush health recommendations for soldiers]. Lek Woj. 1997; 1-2: 93-98.

3. Łańcucki J, Wysocki Cz, Bieliński A: [Foot dermatitis in soldiers]. Lek Woj. 1978; 11-12: 650-655.

4. Ratka P, Popik R, Saracyn T: [The study of factors predisposing to foot dermatitis]. Lek Woj. 1980; 7-8: 359-361.

5. Brzeziński P: [Pitted keratolysis - basic service soldiers disease]. Lek Woj. 2008; 86: 96-98.

6. Brzeziński P: Pitted keratolisis-road rash and rotten odor. Derm Prakt. 2010; 3: 46-48.

7. Schissel DJ: Road rash with a rotten odor. Mil Med 1999; 164: 65-67.

8. Jellife DB, Humphereys J: Lesion of the feet in African soldiers. J Trop Med Hyg 1952; 55: 1-5.

9. Mathis M: Bakteriell bedingter Schweissgeruch bei Trichobacteriosis palmellina und Keratoma sulcatum. Wehrmedizin und Wehrpharmazie 2004; 1: 15-17.

10. Brzeziński P: [„Corynebacterium triad” in soldiers]. N Dermatol Online. 2010; 1: 3-9.

11. Brzeziński P: [Piezogenic nodules - chronic diseases taking place at athletes]. Med Sport. 2009; 25: 183-188.
12. Shenoi SD, Davis SV, Rao S, Rao G, Nair S: Dermatoses among paddy field workers--a descriptive, cross-sectional pilot study. Indian J Dermatol Venereol Leprol. 2005; 71: 254-258.

13. Kanthraj GR, Krupashankar DS, Srinivas CR: Occupational dermatoses among the silk workers. Indian J Dermatol. 1996; 41: 40-44.

14. Stern R, González E, Johnson RA, O’Connell J, Dover JS: Prevalence of skin disease in a cohort of shelter-based homeless men. J Am Acad Dermatol. 1999; 41: 197-202.

15. Zhang ZY, Ying ZW, Zhang SY, Lim JM: Observations on the efficacy of Botai ointment in treating dermatosis common among armed forces receiving at-sea training. Di Yi Jun Yi Da Xue Xue Bao. 2002; 22: 1114-1115.

16. Noguchi H., Hiruma M., Kawada A, Ishibashi A: Tinea pedis survery in members of the Japanese Self-Defense Forces undergoing ranger training. Mycoses. 1994; 37: 461-467.

17. Suo J., Li H., Liang J, Chen S, Yu R: Study of dermatomycosis and survery of pathogenes in troops of Hainan area. Wei Sheng Wu Xue Bao. 1997; 37: 316-318.

18. Esterman A, Pilotto L: Foot shape and its effect on functioning in Royal Australian Air Force recruits. Part 1: Prospective cohort study. Mil Med. 2005; 170: 623-628.

19. Abdel-Fattah MM, Hassanin MM, Felembane FA: Flat foot among Saudi Arabian army recruits: prevalence and risk factors. East Mediterr Health J. 2006; 12: 211-217.

20. Di Benedetto M, Yoshida M, Sharp M, Jones B: Foot evaluation by infrared imaging. Mil Med. 2002; 167: 384-392. 21. Brzeziński P: Skin disorders of the foot during military exercise and their impact on soldier's performance]. Lek. Woj. 2009; 87: 80-83.

\section{Correspondence:}

Cpt. Piotr Brzezinski, MD PhD

Dermatological Clinic, 6th Military Support Unit, os. Ledowo 1N, 76-200 Ustka, Poland

E-mai: Piotr Brzezinski, MD PhD: brzezoo77@yahoo.com 